\title{
Chemical and Bacteriological Impacts of Wastewater on The Water Resources at Atfih Area, Giza Governorate, Egypt
}

\author{
Salah A. Abo-ElEnien', Mostafa H. Khalil ${ }^{1}$, ${ }^{* *}$ Yahia R. Gedamy ${ }^{2}$ and Heba Z. \\ Salem $^{1^{*}}$ \\ ${ }^{1}$ Department of Chemistry, Faculty of Science, Ain Shams University, and \\ ${ }^{2}$ Hydrogeochemistry Department, Desert Research Center, Cairo, Egypt.
}

\begin{abstract}
THE PRESENT work is aimed to detect the pollutants in the water resources (surface water and groundwater) and their impact on human health as well as evaluate these water resources for different purposes at Atfih area which occupies the southern portion of Giza governorate. To achieve the aim of the present study, fifty water samples (surface water and groundwater samples) are collected during March (2016) and chemically analyzed for detection of inorganic and bacteriological pollutants. Drinking and agriculture in this area depend mainly on the water of Nile River and two main canals namely El Khashab and Masjid Musa canals as well as groundwater. The results indicated that, El Khashab and Masjid Musa canals are subjected to pollution from different sources. Also, the shallow groundwater tapped from the near surface quaternary deposits is also subjected to pollution. The socalled El Saff wastewater canal represents one of the main sources of pollution for the water resources in the study area. This canal runs longitudinally for about $50 \mathrm{~km}$ along the foot slopes of the eastern Eocene escarpment. All the detected pollutants are considered very serious to people's health. The most important pollution problem sources include the wastewater produced from the industrial complex at Helwan area in addition to the wastewater discharged from El Saff wastewater canal into the Nile River and its canals. On the other hand, the excessive seepage of drainage water rich in fertilizers and pesticides causes pollution for groundwater. Majority of surface water (El Khashab and Masjid Musa canals) samples and groundwater samples in the study area are unsuitable for drinking as they have $\mathrm{Fe}, \mathrm{Sr}, \mathrm{B}$ and $\mathrm{NO}_{3}{ }^{-}$more than that of the permissible limit.In conclusion, most of the surface water and groundwater samples in the study area are suitable for irrigation.
\end{abstract}

.Keywords: Atfih area (Egypt), water pollution, inorganic pollutants, bacteriological Pollutants

\section{Introduction}

Atfih area lies nearly $70 \mathrm{~km}$ to the southeast of Cairo along the eastern side of the Nile River between latitudes $29^{\circ} 23^{`}$ and $29^{\circ} 37^{`} \mathrm{~N}$, and longitudes $31^{\circ} 15$ and $31^{\circ} 25^{\backslash} \mathrm{E}$ (Fig.1). It is bounded by El Saff city to the North, El Kuraimat city to the South, El Saff waste water canal to the East and Nile River to the West.

Atfih area is located in the extreme arid belt of Egypt which is characterized by long hot summer and short warm winter, low rainfall and high evaporation rate. The average temperature varies from $37^{\circ} \mathrm{C}$ (summer) to $15^{\circ} \mathrm{C}$ (winter). The mean annual rainfall is low and ranges between $4.2 \mathrm{~mm} / \mathrm{y}$ to $17.4 \mathrm{~mm} / \mathrm{y}$. Evaporation is generally varying from $18.7 \mathrm{~mm} /$ day (May) and $2.3 \mathrm{~mm} /$ day (December), while the highest value of relative humidity $(71.8 \%)$ is recorded in December [3].

Water pollution problems have led to serious ecological and environmental problems. As it adversely affects the human health and the biodiversity in the aquatic ecosystem.

The Nile River, which represents more than 90\% of the Nile basins water resources, is the traditional receptor of waste and drainage waters generated by different activities [1,2]. which effects on human health, plants and animals in Atfih area (case study).

So, Attih area is nowadays suffering remarkable rise in groundwater levels (water logging) resulting in the flooding of vast areas of good fertile soil and destruction of building and roads. Consequently, salt lands, ponds and pollution of environment are intensely spreaded [3].

Drinking and agriculture in this area depend mainly on the water of Nile River and two main canals namely El khashab and Masjid Musa canals as well as groundwater. Such canals are subjected to pollution from different sources.

Noteworthy to mention that, the high levels of 
iron lead to a condition called hemochromatosis. This can lead to diseases such as arthritis and diabetes and cause damage to the liver and heart [4]. Also, some of the symptoms associated with strontium toxicity include Chronic renal failure, bone diseases, bone deformities, impaired bone growth and bone tumors [5]. Plus, in the case of radioactive strontium, it acts as a human carcinogen. Whereas, the high level of nitrate lead to lack of oxygen which causes death and boron is necessary for plant growth, but an excess of boron is toxic to plants, and occurs particularly in acidic soil [6].

Also, one of the most important factors of water pollution is the microbial contamination; especially with pathogenic microorganisms. Enteric pathogens are typically responsible for waterborne diseases $[7,8]$.

Pathogens are a serious concern for managers of water resources, because excessive amounts of faecal bacteria in sewage and urban runoff have been known to indicate risk of pathogen-induced illnesses in humans [9].

Several species of gram-negative bacteria present in municipal wastewater are pathogenic.
This pathogenicity is usually associated with certain components of the cell walls, in particular the lipopolysaccharide, also known as LPS or endotoxinlayer [10]. Thus, identification of these pathogenic agents in water resources is beneficial for controlling and prevention planning of the infectious diseases.

Unfortunately, The Nile receives heavy loads of industrial, agricultural and domestic wastes. Drinking water must meet specific criteria and standards to ensure that water supplied to the public is safe and free-from pathogenic microorganisms as well as hazardous compounds [11].

For a long time, pollution problems are ignored and their effect on the environment was not given due consideration. Consequently, pronounced efforts are needed to control such pollution.

The objectives of this study are;

1- To give an overall picture of the pollutants and their sources.

2- Pollution loads and water quality determination.

3-The impacts of pollutants on the human health and evaluation of water resources for different purposes.

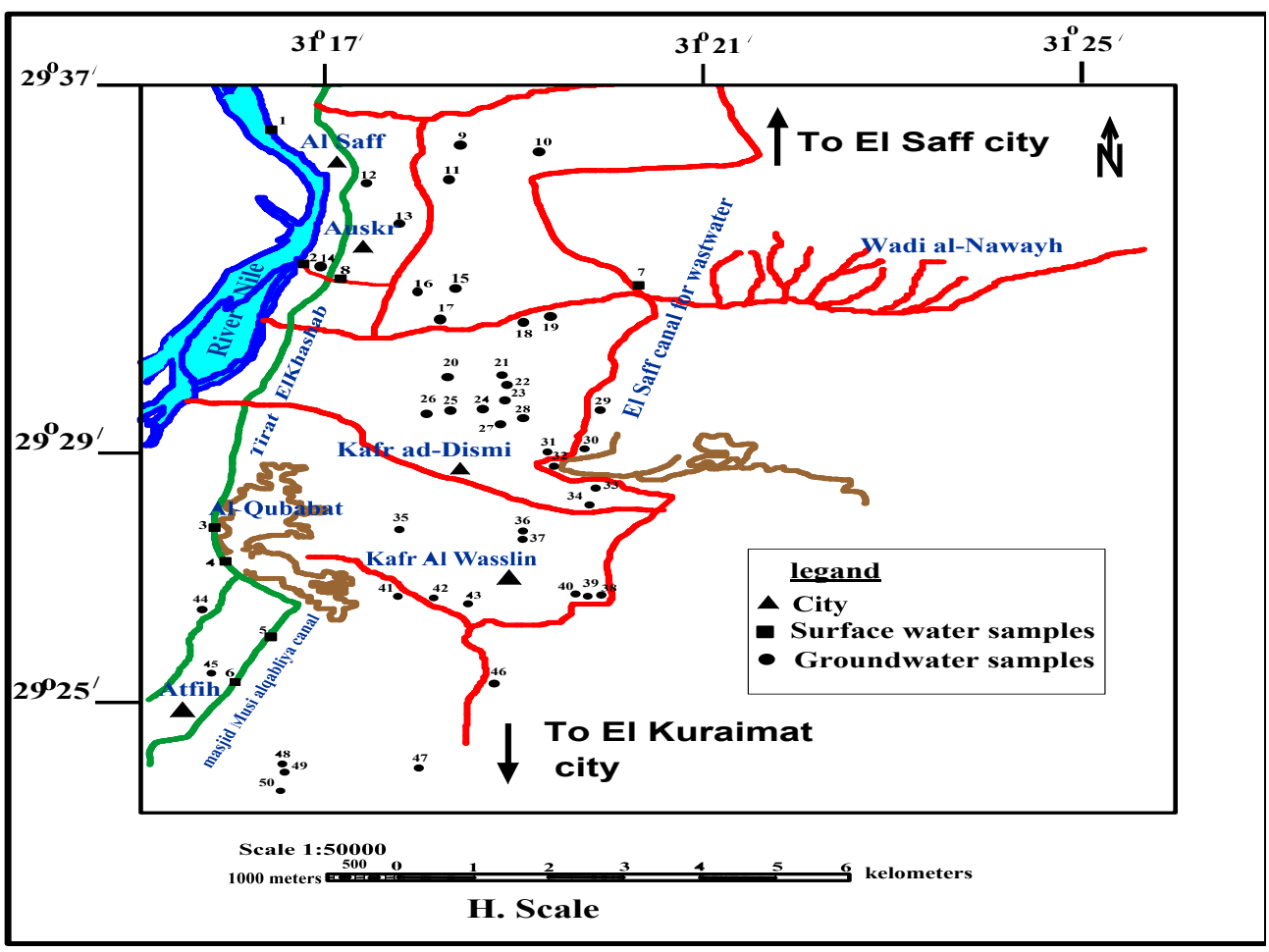

Fig. 1. The location map of the study area. 


\section{Materials and Methods}

\section{Water sampling}

Field trip took place within March (2016), during which surface water and groundwater samples were manually and aseptically collected from the study area. The sampling sites used to provide the data reported in this paper appear in Fig. 1. The present research is based on the results of fifty(50) water samples collected from the study area and representing all available water sources. The collected water samples included surface water (8 samples) and groundwater (42 samples) in Atfih area were obtained for chemical and bacteriological analyses. These water samples were collected from their water points and separated into three aliquots. One of aliquots was acidified with nitric acid $(1 \%)$ and stored in polyethylene bottles for the measurements of trace elements and soluble heavy metals. The second aliquot was taken in polyethylene bottle $(100 \mathrm{ml})$ to measure the minor constituents as boron and nitrate. The third aliquot was taken in special container $(100 \mathrm{ml})$ for the measurements of microbiological and pathological analyses of water. These water samples were immediately kept in the dark, cooled in an insulated container and transported to the laboratory within $10 \mathrm{~h}$. and stored at $4^{\circ} \mathrm{C}$ until bacteriological analysis was completed within $24 \mathrm{~h}$. of collection as specified in standard national and international methods.

\section{Laboratory analyses}

The analyses included the determination of inorganic constituents(B, Al, Fe, Mn, Cu, Ni, Pb, Srand $\mathrm{Zn}$ ) that measured using ICAP model (thermo 6500) according to (ASTM) [12]. Also, the concentration of nitrate $\left(\mathrm{NO}_{3}^{-}\right)$was determined by colorimetric methods using UV/Visible spectrophotometer (Thermo-Spectronic 300) according to Fishman, and Friedman[13]. The obtained chemical data were expressed in milligram per liter (mg/l) or part per million (ppm). The total viable bacterial counts (TVBCs) at $22^{\circ} \mathrm{C}$ and $37^{\circ} \mathrm{C}$ were determined using the spread-plate method [14]. The numbers of total and faecal coliforms were determined using the most probable number (MPN) method using MacConkey broth media. The positive tubes were streaked on the Eosin Methylene Blue (EMB) agar plates. Microscopic examination was carried out to ensure gram-negative, non-spore forming rods [14]. MPN of faecal streptococci was determined using azide dextrose broth at $37^{\circ} \mathrm{C}$ for $48 \mathrm{hr}$. Positive tubes were indicated by dense turbidity and confirmed using ethyl violet azide dextrose broth incubated at $37^{\circ} \mathrm{C}$ for $24 \mathrm{hr}$. [14]. The isolation of gram-negative bacteria for groundwater samples in the study area were performed using MacConkey agar supplemented with $0.001 \mathrm{~g} / \mathrm{L}$ crystal violet [15]. Several isolates were purified, screened and the suspected similar ones were grouped for the purpose of selection and identification processes. Isolates from the examined water samples were subjected to identification by biochemical characteristics using API 20E strip system (BioMereux). Each API 20E strip consists of thirty five water points containing dehydrated media. The isolate to be tested was suspended in sterile saline and added to each water sample. The inoculated strip was incubated for $16-24 \mathrm{~h}$ and the color reactions were noted either positive or negative.

\section{Result and Discussion}

To achieve the main aim of this research, water pollution will be discussed on the basis of determining inorganic and bacteriological analyses (Tables 1, 2 and 3) with regard to the recommended levels of contamination according to national guide limits as (WHO) [11] and Fishman and Friedman [13].

\section{Inorganic pollutants}

The inorganic pollutants in the water samples at the study area are discussed through the measurements of $\mathrm{Al}, \mathrm{Fe}, \mathrm{Mn}, \mathrm{Cu}, \mathrm{Ni}, \mathrm{Pb}, \mathrm{Sr}$ and $\mathrm{Zn}$ as well as $\mathrm{B}$ and $\mathrm{NO}_{3}{ }^{-}$

By comparing the obtained result (Tables 1 and 2) with the permissible limits as presented by (WHO) [16], it is clear that;

The Nile River water sample at this locality is still safe as it contains $\mathrm{Al}, \mathrm{Fe}, \mathrm{Mn}, \mathrm{Cu}, \mathrm{Ni}, \mathrm{pb}, \mathrm{Sr}$, and $\mathrm{Zn}$ concentrations less than the acceptable limits as presented by (WHO) [16], (Fig. 2, 3, 4 and 5). While, it is clear that the mixed water sample (Nile River water mixed with wastewater) is polluted as it contains $\mathrm{Fe}$ and $\mathrm{Sr}$ as well as $\mathrm{B}$ concentration more than the acceptable limits [16]. This is because of the industrial wastewater that drained into the wastewater canal as well as excessive use of fertilizers (Fig. 2, 3 and 4).

El Khashab and Masjid Musa canals water samples were polluted as they have $\mathrm{Fe}$ and $\mathrm{B}$ concentrations $(0.925-9.66 \mathrm{mg} / \mathrm{L})$ and $(6.58$ $9.55 \mathrm{mg} / \mathrm{L})$, respectively. This is due to thatthese canals received industrial wastes from factories existed in the study area that discharged their wastes in these canals at these localities as well as excessive use of fertilizers (Fig. 2 and 4).

All El Saff canal water samples are Egypt. J. Chem. 60, No.6 (2017) 
contaminated as they have $\mathrm{Fe}$ and $\mathrm{Sr}$ as well as $\mathrm{B}$ and $\mathrm{NO}_{3}^{-}$concentrations (3.97 - $\left.7.25 \mathrm{mg} / \mathrm{L}\right)$, (3.26 - $7.52 \mathrm{mg} / \mathrm{L}),(2.14-16.84 \mathrm{mg} / \mathrm{L})$ and $(95-$ $134.4 \mathrm{mg} / \mathrm{L})$ respectively, more than the acceptable limits of pollution.This is due to that El Saff wastewater canal acts as a drain for discharging large amounts of irrigation drainage water containing impurities of soluble metals from the intensive use of fertilizers and pesticides together with industrial wastes discharged into this canal at south Helwan area (Fig. 2, 3, 4 and 5).

Majority of the groundwater samples in the study area $(90 \%)$ were polluted as they have $\mathrm{Fe}, \mathrm{Sr}, \mathrm{B}$ and $\mathrm{NO}_{3}{ }^{-}$concentrations more than the acceptable limits of pollution in different portions (Fig. 6, 7, 8 and 9). This is due to the seepage from El Khashab and Masjid Musa canals as well as El Saff wastewater canal that contains relatively high soluble metals as well as downward infiltration of excess amounts of

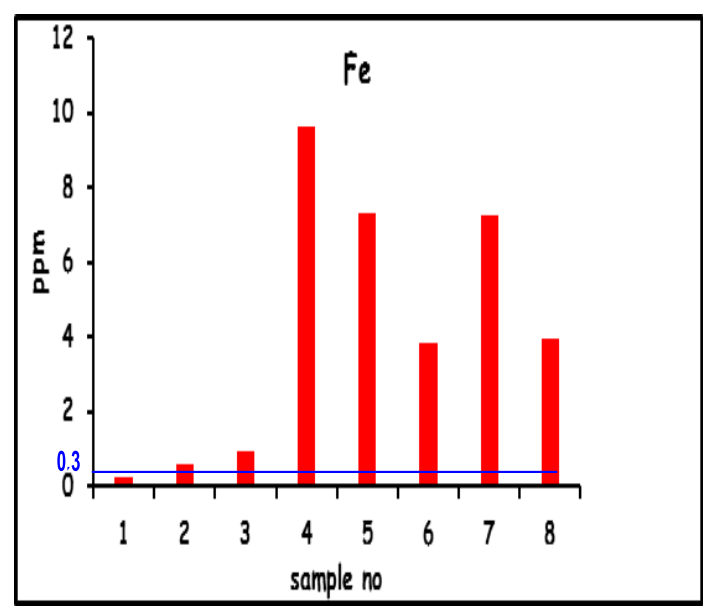

Fig 2. The concentration of $\mathrm{Fe}$ in the surface water sample, in study area.

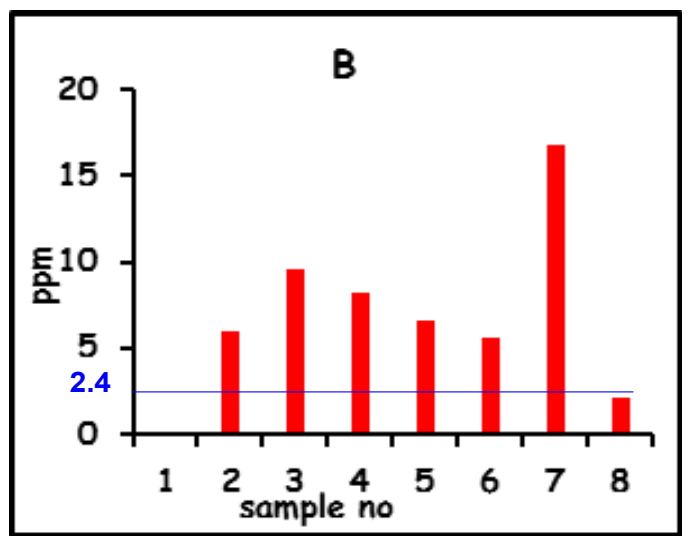

Fig. 4. The concentration of $B$ in the surface water sample, in study area. irrigation water rich in fertilizers and pesticides to the groundwater. Noteworthy, the primary source of nitrates in groundwater is the leaching of nitrate salts into the groundwater supply from agricultural fertilization and the seepage of sewage water. This is manifested by Schilling and Wolter [17] and Liu [18] that stated agricultural practices result in nonpoint-source pollution of groundwater, and the effect of these practices accumulate over time. Point sources of nitrogen such as septic systems have been shown to contribute to nitrate pollution of groundwater.
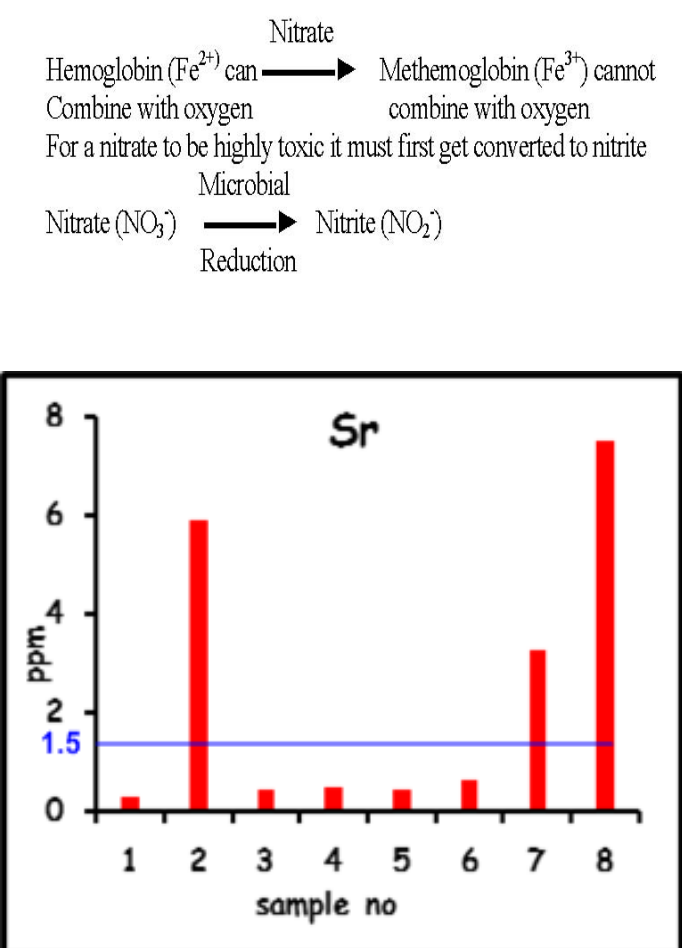

Fig.3. The concentration of $\mathrm{Sr}$ in the surface water sample, in study area.

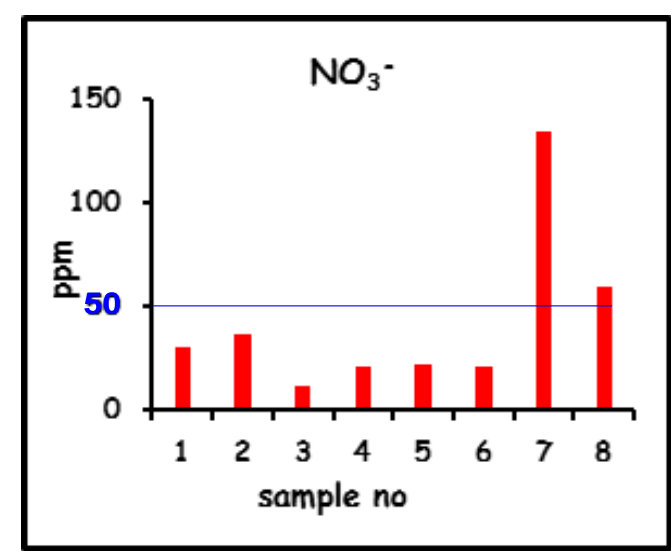

Fig. 5. The concentration of $\mathrm{NO}_{3}^{-}$in the surface water sample, in study area. 
TABLE 1. The concentration of trace elements in the water samples at the study area expressed as ppm.

\begin{tabular}{|c|c|c|c|c|c|c|c|c|c|}
\hline $\begin{array}{c}\text { Sample } \\
\text { No. }\end{array}$ & Al & $\mathrm{Cr}$ & $\mathrm{Cu}$ & Fe & Mn & Ni & $\mathbf{P b}$ & $\mathbf{S r}$ & Zn \\
\hline \multicolumn{10}{|c|}{ Surface water samples } \\
\hline \multicolumn{10}{|c|}{ River Nile water sample } \\
\hline 1 & .015 & .0006 & ND & .249 & .024 & ND & ND & .3 & ND \\
\hline \multicolumn{10}{|c|}{ Mixed water sample } \\
\hline 2 & .126 & ND & .001 & .582 & .113 & .001 & ND & 5.91 & .005 \\
\hline \multicolumn{10}{|c|}{ EL Khashab canal water samples } \\
\hline 3 & .049 & .004 & ND & .926 & .018 & .001 & ND & .452 & .009 \\
\hline 4 & .064 & ND & ND & 9.66 & .071 & .001 & ND & .472 & .037 \\
\hline \multicolumn{10}{|c|}{ Masjid Musa canal water samples } \\
\hline 5 & .081 & ND & ND & 7.31 & .058 & .0001 & ND & .448 & .065 \\
\hline 6 & .017 & ND & ND & 3.82 & .044 & ND & ND & .63 & .154 \\
\hline \multicolumn{10}{|c|}{ EI Saff canal for waste water samples } \\
\hline 7 & 1.06 & .011 & .911 & 7.25 & .087 & .009 & .0045 & 3.26 & .244 \\
\hline 8 & .119 & .003 & ND & 3.97 & .114 & .002 & ND & 7.52 & .039 \\
\hline \multicolumn{10}{|c|}{ Pleistocene aquifer of groundwater samples } \\
\hline 9 & .029 & ND & ND & .097 & .0003 & ND & ND & 3.95 & .139 \\
\hline 10 & ND & ND & .003 & .02 & ND & ND & .0014 & 4.87 & .256 \\
\hline 11 & .036 & .019 & .0001 & .11 & ND & .0002 & ND & 4.63 & .015 \\
\hline 12 & ND & ND & .004 & 5.91 & .046 & ND & ND & .616 & 1.82 \\
\hline 13 & ND & .006 & ND & .015 & ND & ND & ND & 7.66 & ND \\
\hline 14 & ND & ND & ND & .104 & .011 & ND & ND & 1.67 & .009 \\
\hline 15 & .108 & .0008 & .001 & .11 & .004 & ND & ND & 2.01 & .051 \\
\hline 16 & ND & ND & ND & .059 & .015 & ND & ND & .614 & .295 \\
\hline 17 & ND & ND & ND & .037 & ND & ND & ND & 5.52 & .101 \\
\hline 18 & .036 & .007 & 1.75 & .167 & .0004 & .001 & ND & 7.65 & .002 \\
\hline 19 & .056 & ND & .003 & .117 & ND & .0005 & ND & .389 & .021 \\
\hline 20 & .009 & .007 & .351 & .048 & ND & .0004 & ND & 18.32 & .001 \\
\hline 21 & .449 & .015 & .136 & .791 & .017 & .002 & ND & 8.23 & .006 \\
\hline 22 & ND & .007 & ND & 1.75 & .032 & .005 & ND & 10.88 & ND \\
\hline 23 & .012 & .002 & .019 & .371 & .002 & .0007 & ND & 13.38 & .0004 \\
\hline 24 & ND & ND & .057 & ND & .024 & .0001 & ND & 11.42 & ND \\
\hline 25 & ND & .009 & .04 & ND & ND & .001 & ND & 15 & ND \\
\hline 26 & .024 & .005 & .215 & ND & ND & .001 & ND & 16.46 & ND \\
\hline 27 & ND & ND & .009 & .119 & ND & .0002 & ND & 13.69 & ND \\
\hline 28 & .027 & ND & .004 & .009 & ND & ND & ND & 8.37 & .007 \\
\hline 29 & .036 & .001 & .009 & .186 & .013 & .0003 & $\mathrm{ND}$ & 8.99 & .22 \\
\hline 30 & .089 & .029 & .323 & 2.62 & .036 & .003 & .0137 & 4.17 & 9.77 \\
\hline 31 & .326 & .004 & .011 & 1.75 & .01 & .0005 & ND & 8.94 & .004 \\
\hline 32 & ND & .018 & .004 & .059 & ND & .002 & ND & 6.09 & .043 \\
\hline
\end{tabular}


TABLE 1. Cont.

\begin{tabular}{|c|c|c|c|c|c|c|c|c|c|c|}
\hline $\begin{array}{c}\text { Sample } \\
\text { No. }\end{array}$ & Al & $\mathbf{C r}$ & $\mathbf{C u}$ & $\mathbf{F e}$ & $\mathbf{M n}$ & Ni & Pb & Sr & Zn \\
\hline \multicolumn{7}{|c|}{ Pleistocene aquifer of groundwater samples } \\
\hline 33 & .009 & .006 & ND & 1.54 & .021 & ND & ND & 13.21 & .025 \\
\hline 34 & ND & .004 & ND & .022 & ND & ND & ND & 7.39 & .018 \\
\hline 35 & .123 & .0004 & ND & .296 & .009 & ND & ND & 10.92 & .006 \\
\hline 36 & .0002 & .01 & ND & .095 & ND & ND & ND & 16.95 & ND \\
\hline 37 & ND & .01 & .004 & .008 & ND & ND & ND & 16.77 & ND \\
\hline 38 & ND & .019 & ND & .009 & ND & ND & ND & 21.06 & .001 \\
\hline 39 & .0006 & .007 & ND & ND & ND & ND & ND & 9.11 & .001 \\
\hline 40 & ND & .004 & ND & .043 & ND & .0006 & ND & 6.77 & .041 \\
\hline 41 & ND & .003 & ND & .062 & ND & ND & ND & 2.48 & .007 \\
\hline 42 & ND & .007 & ND & .074 & ND & ND & ND & 3.2 & .004 \\
\hline 43 & ND & .007 & ND & .24 & ND & ND & ND & 5.98 & .016 \\
\hline 44 & ND & ND & .001 & 4.29 & .793 & .002 & .007 & .878 & .049 \\
\hline 45 & .003 & .007 & ND & .067 & .298 & ND & ND & .63 & .154 \\
\hline 46 & .017 & .014 & ND & .139 & ND & ND & ND & 5.63 & .007 \\
\hline 47 & .225 & .009 & ND & .138 & ND & ND & ND & 6.36 & .005 \\
\hline 48 & ND & ND & ND & .043 & .0004 & ND & ND & 9.24 & .021 \\
\hline 49 & ND & .002 & ND & .028 & ND & ND & ND & 6.94 & .002 \\
\hline 50 & ND & .007 & ND & .015 & ND & ND & ND & 7.88 & ND \\
\hline $\begin{array}{c}\text { Safe } \\
\text { limit }\end{array}$ & $\mathbf{0 . 2}$ & $\mathbf{0 . 0 5}$ & $\mathbf{2}$ & $\mathbf{0 . 3}$ & $\mathbf{0 . 4}$ & $\mathbf{0 . 0 7}$ & $\mathbf{0 . 0 1}$ & $\mathbf{1 . 5}$ & $\mathbf{0 . 0 5}$ \\
\hline
\end{tabular}

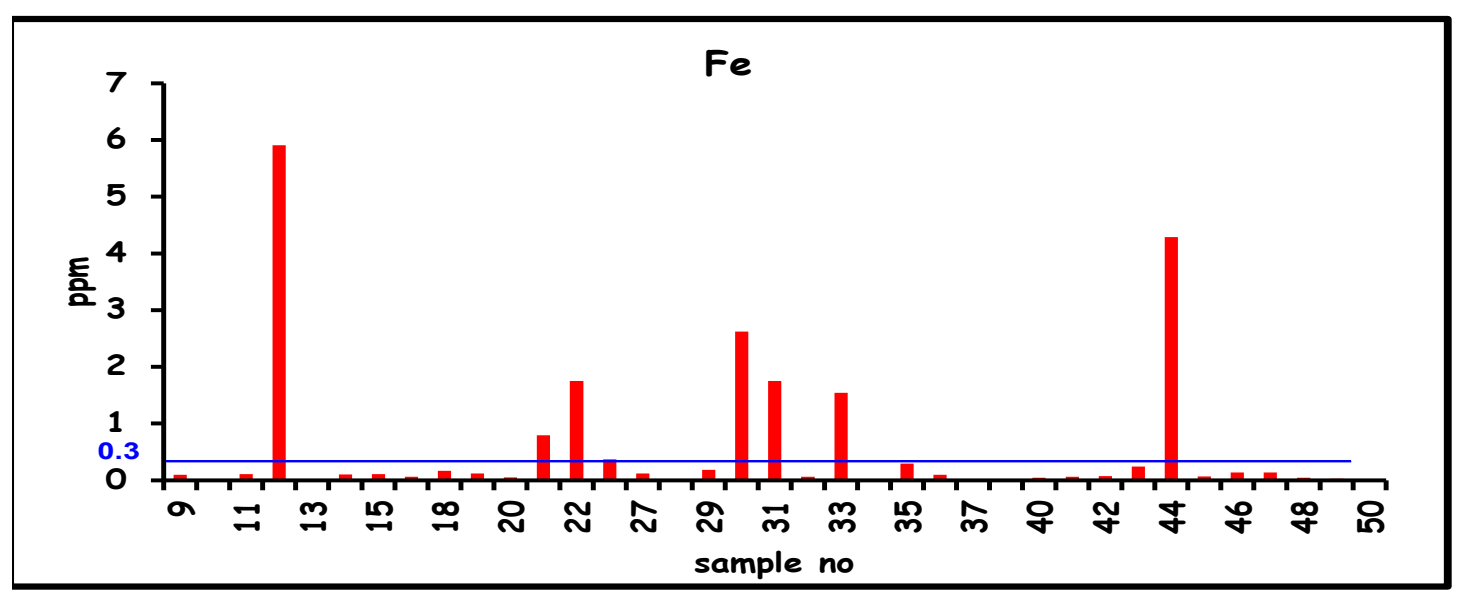

Fig. 6. The concentration of $\mathrm{Fe}$ in the groundwater sample, in study area.

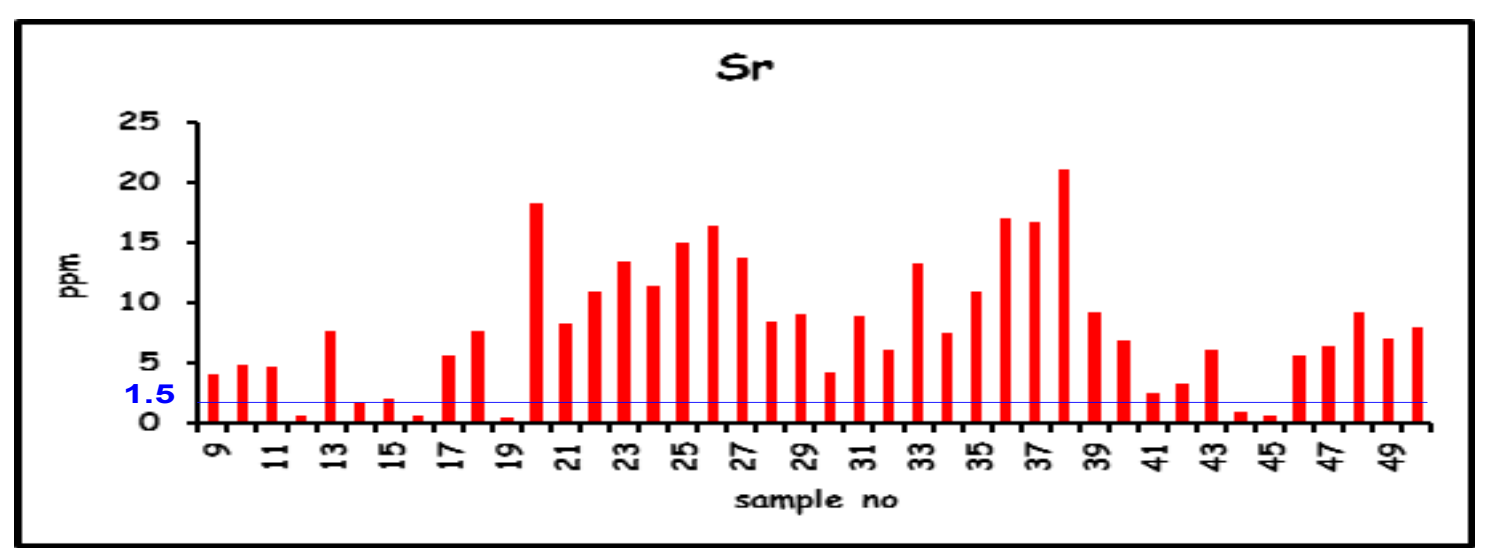

Fig. 7. The concentration of $\mathrm{Sr}$ in the groundwater sample, in study area. 
TABLE 2. The concentration of $\mathrm{B}$ and $\mathrm{NO}_{3}^{-}$in the water samples at the study area expressed as ppm.

\begin{tabular}{|c|c|c|c|c|c|}
\hline $\begin{array}{c}\text { Sample } \\
\text { No. }\end{array}$ & B & $\mathrm{NO}_{3}^{-}$ & $\begin{array}{c}\text { Sample } \\
\text { No. }\end{array}$ & B & $\mathrm{NO}_{3}^{-}$ \\
\hline \multicolumn{3}{|c|}{ Surface water samples } & \multicolumn{3}{|c|}{ Pleistocene aquifer of groundwater samples } \\
\hline \multicolumn{3}{|c|}{ River Nile water sample } & 23 & 14.44 & 233.8 \\
\hline 1 & ND & 30.1 & 24 & 15 & 114.3 \\
\hline \multicolumn{3}{|c|}{ Mixed water sample } & 25 & 16.17 & 181.7 \\
\hline 2 & 5.96 & 36.3 & 26 & 16.97 & 239 \\
\hline \multicolumn{3}{|c|}{ EL Khashab canal water samples } & 27 & 14.12 & 136.6 \\
\hline 3 & 9.55 & 10.6 & 28 & 12.44 & 143.3 \\
\hline 4 & 8.27 & 20.3 & 29 & 11.35 & 116.6 \\
\hline \multicolumn{3}{|c|}{ Masjid Musa canal water samples } & 30 & 11.17 & 214.7 \\
\hline 5 & 6.62 & 21.7 & 31 & 12.09 & 102.2 \\
\hline 6 & 5.58 & 20.1 & 32 & 10.55 & 90.3 \\
\hline \multicolumn{3}{|c|}{ EI Saff canal for waste water samples } & 33 & 10.49 & 158.6 \\
\hline 7 & 16.84 & 134.4 & 34 & 9.19 & 95.9 \\
\hline 8 & 2.14 & 59 & 35 & 8.53 & 93.8 \\
\hline \multicolumn{3}{|c|}{ Pleistocene aquifer of groundwater samples } & 36 & 10.29 & 103.5 \\
\hline 9 & 0.379 & 139 & 37 & 10.16 & 122.5 \\
\hline 10 & 0.18 & 117.8 & 38 & 10.53 & 161.2 \\
\hline 11 & 0.827 & 113.2 & 39 & 9.53 & 56.6 \\
\hline 12 & $\mathrm{ND}$ & 177 & 40 & 10.2 & 104.1 \\
\hline 13 & 6.62 & 108.1 & 41 & 7.07 & 32.6 \\
\hline 14 & 5.43 & 37.6 & 42 & 7.74 & 75.1 \\
\hline 15 & 0.003 & 114 & 43 & 7.16 & 42.7 \\
\hline 16 & 0.048 & 66.6 & 44 & 6.57 & 15.6 \\
\hline 17 & 0.135 & 72.4 & 45 & 6.05 & 71.4 \\
\hline 18 & 16.83 & 93.6 & 46 & 8.04 & 101.6 \\
\hline 19 & 0.081 & 76.9 & 47 & 6.79 & 98.1 \\
\hline 20 & 17.15 & 153.8 & 48 & 6.08 & 74.3 \\
\hline 21 & 13.82 & 202.1 & 49 & 5.98 & 67.9 \\
\hline 22 & 13.47 & 117.8 & 50 & 6.42 & 83.6 \\
\hline Safe limit & 2.4 & 50 & Safe limit & 2.4 & 50 \\
\hline
\end{tabular}

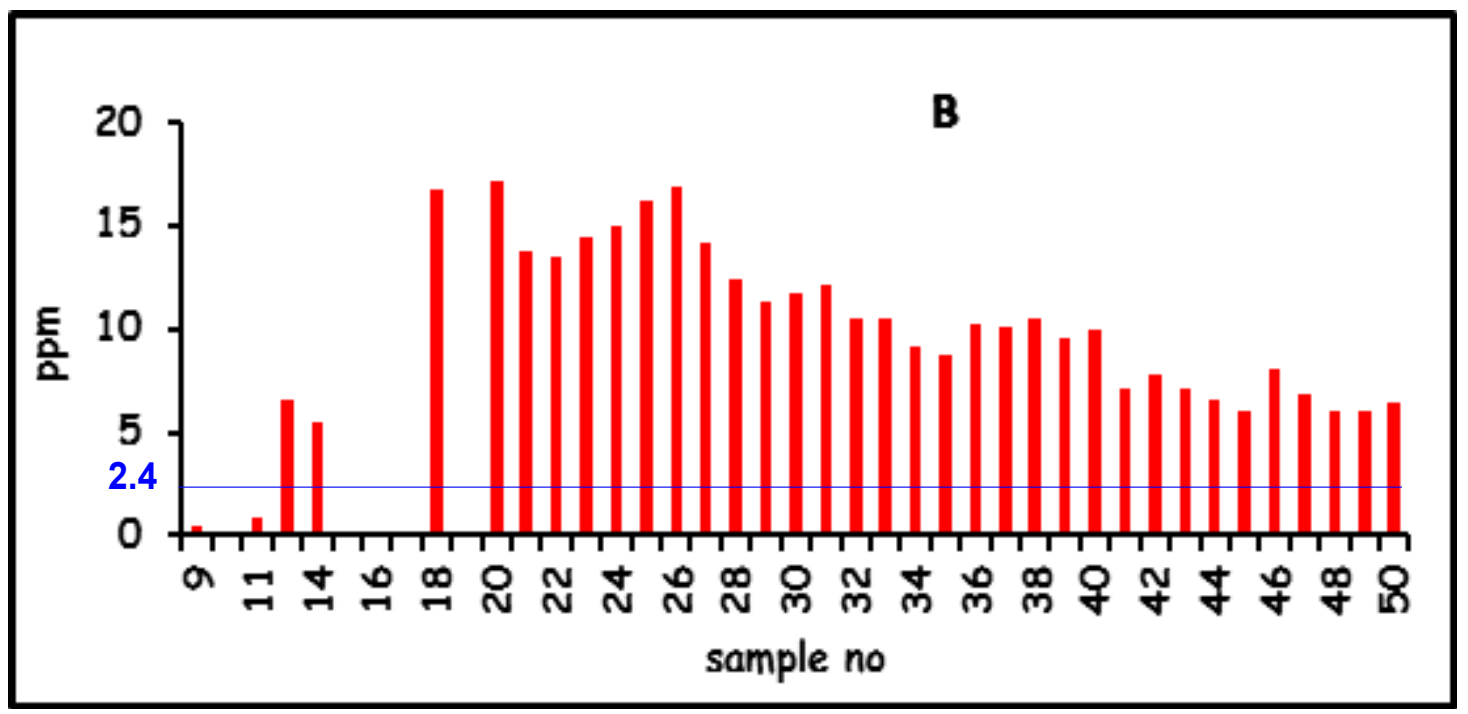

Fig. 8. The concentration of $B$ in the groundwater sample, in study area. 


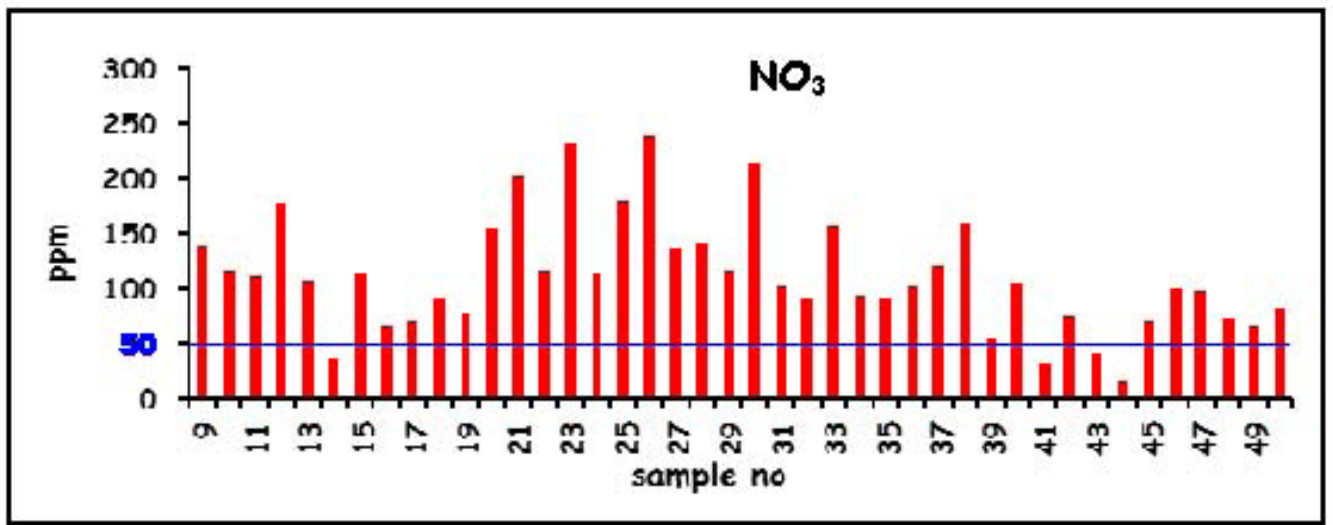

Fig. 9. The concentration of $\mathrm{NO}_{3}^{-}$in the groundwater sample, in study area.

\section{The bacteriological pollutants}

The bacteriological analyses involved total viable bacterial counts (TVBCs), total coliforms (TC) and estimation of faecal coliforms (FC), faecal streptococci and bacteria.

The results of the total number of bacteria are shown in Table 3. The total number of bacteria ranged from $2 \times 10^{4}$ to $276 \times 10^{4} \mathrm{cfu} / \mathrm{ml}$ and from $4 \times 10^{4}$ to $361 \times 10^{4} \mathrm{cfu} / \mathrm{ml}$ at $22^{\circ} \mathrm{C}$ and $37^{\circ} \mathrm{C}$, respectively.

The most probable number (MPN) of faecal indicators total coliforms (TC), faecal coliforms (FC) and faecal streptococci (FS) are shown in Table 3.

MPN of TC varied from 10 to $1800 / 100 \mathrm{ml}$ and from 2 to $430 / 100 \mathrm{ml}$ water for FC. The counts of FS fluctuated between 2 and $210 / 100 \mathrm{ml}$ water in Atfih area.

The highest bacterial indicators were recorded at Atfih area and this might be explained by the effect of domestic and agricultural wastes discharge from the urbanized surrounding area [19].

The ratio $\mathrm{FC} / \mathrm{FS}$ points to the source of faeces whether it is human $(>4)$ or animal $(<0.7)$ as represented by Geldreich [20], accordingly, the FC/FS ratio was in the range of $0.29-16.6$ and $0.5-65$, respectively with irrigation canals and groundwater which mean the mixed origin of faecal pollution.
According to the guideline criteria for faecal indicator organisms of (WHO) [11] which accept the guide values of the investigated bacteria up $500 / 100 \mathrm{ml}$ for total coliforms and $100 / 100 \mathrm{ml}$ for both faecal coliforms and faecal streptococci, the survey of the indicator bacteria along Atfihwater resources revealed that the Nile River water at this branch is subjected to sewage pollution.

In the present study, the isolates of genus 1 were differentiated and confirmed by Ap $120 \mathrm{E}$ as E. coil (Table 4), E. coil is the main indicator of faecal pollution, which causes diarrhea, vomiting and fever, this also indicated that all water resources of Atfih area are subjected sewage pollution.

Based on morphological and AP1 20 biochemical reactions (Table 4), most members of genus 2 are identified as Pseudomonas fluorescence. At present, the genus Klebsiella is subdivided into 5 species [21]. The isolates of genus 3 were identified as Klebsiella pneumonia according to morphological and biochemical characteristics (Table 4). K. pneumonia represented $14 \%$ of the identified gram negative bacteria isolated from Atfih area. This pathogenic bacterium has been previously isolated from surface water [22]. There are 2200 known species of Salmonella which cause intestinal infection such as salmonellosis. The species of genus 4 was classified as salmonella cloerasuls because of its biochemical characteristics (Table 4). Such pathogenic bacterium constituted $11 \%$ of gramnegative bacteria from the examined water. On the other hand, isolated of genus 5 were identified 
as Shigella sp and represented 9\% of the identified gram negative bacteria. This pathogenic bacterium is an invasive pathogen which causes shigellasis or shigella-related diarrhea. On the other, genus 6 includes 8 isolates $(8 \%)$ of gram-negative bacteria which were identified asproteus vulgaris (Table 4).

TABLE 3. The total viable bacterial counts $(T V B C s) \times 10^{4} \mathrm{cfu} / \mathrm{ml}$, the most probable number (MPN) of total coliforms (TC), faecal coliforms (FC) and faecal streptococci (FS)/100ml water Atfih area.

\begin{tabular}{|c|c|c|c|c|c|c|}
\hline \multirow{2}{*}{ Sample No. } & \multicolumn{2}{|c|}{$\begin{array}{l}\text { Total viable bacteria } \times 10^{4} \mathrm{cfu} \\
\mathrm{ml}\end{array}$} & \multirow{2}{*}{$\begin{array}{c}\text { Total } \\
\text { coliform }\end{array}$} & \multirow{2}{*}{$\begin{array}{l}\text { Faecal } \\
\text { Coliform }\end{array}$} & \multirow{2}{*}{$\begin{array}{c}\text { Faecal } \\
\text { Streptococci }\end{array}$} & \multirow{2}{*}{ FC/FS } \\
\hline & $22^{\circ} \mathrm{C}$ & $37^{\circ} \mathrm{C}$ & & & & \\
\hline \multicolumn{7}{|c|}{ Surface water } \\
\hline \multicolumn{7}{|c|}{ Nile River water } \\
\hline 1 & 35 & 43 & - & - & - & - \\
\hline \multicolumn{7}{|c|}{ Mixed water } \\
\hline 2 & 27 & 32 & 15 & 8 & 2 & 4 \\
\hline \multicolumn{7}{|c|}{ El khashab and Masjid Musa canals water } \\
\hline 3 & 96 & 120 & 275 & 28 & 10 & 2.8 \\
\hline 4 & 192 & 244 & 225 & 71 & 59 & 1.2 \\
\hline 5 & 103 & 130 & 275 & 20 & 69 & 0.29 \\
\hline 6 & 16 & 29 & 10 & 83 & 5 & 16.6 \\
\hline \multicolumn{7}{|c|}{ El Saff wastewater canal } \\
\hline 7 & 219 & 264 & 1350 & 310 & 205 & 1.51 \\
\hline 8 & 142 & 232 & 900 & 360 & 76 & 4.56 \\
\hline \multicolumn{7}{|c|}{ Selected groundwater samples } \\
\hline 10 & 11 & 15 & - & - & - & - \\
\hline 11 & 11 & 19 & - & - & - & - \\
\hline 12 & 9 & 17 & - & - & - & - \\
\hline 13 & 18 & 24 & - & - & - & - \\
\hline 14 & 15 & 23 & - & - & - & - \\
\hline 15 & 41 & 65 & - & - & - & - \\
\hline 17 & 206 & 252 & 350 & 260 & 4 & 65 \\
\hline 20 & 11 & 19 & - & - & - & - \\
\hline 25 & 5 & 10 & - & - & - & - \\
\hline 26 & 180 & 230 & 900 & 430 & 210 & 2.05 \\
\hline 27 & 20 & 35 & - & - & - & - \\
\hline 29 & 6 & 9 & - & - & - & - \\
\hline 30 & 47 & 52 & - & - & - & - \\
\hline 33 & 19 & 28 & - & - & - & - \\
\hline 35 & 59 & 106 & 25 & 2 & 4 & 0.5 \\
\hline 36 & 63 & 86 & - & - & - & - \\
\hline 42 & 50 & 72 & - & - & - & - \\
\hline 44 & 14 & 22 & - & - & - & - \\
\hline 45 & 62 & 75 & - & - & - & - \\
\hline 47 & 67 & 90 & - & - & - & - \\
\hline 48 & 18 & 24 & - & - & - & - \\
\hline 50 & 2 & 4 & - & - & - & - \\
\hline Safe limit & 0 & 0 & 0 & 0 & 0 & 0 \\
\hline
\end{tabular}


TABLE 4. API 20E biochemical characteristics pathogenic of Gram-Negative bacteria isolated from Atfih area.

\begin{tabular}{|c|c|c|c|c|c|c|}
\hline Type & Genus 1 & Genus 2 & Genus 3 & Genus 4 & Genus 5 & Genus 6 \\
\hline ONPG & + & - & + & - & - & - \\
\hline $\mathrm{ADH}$ & - & + & - & - & - & - \\
\hline LDC & - & - & - & + & + & - \\
\hline ODC & - & - & - & + & + & - \\
\hline CIT & - & + & + & - & - & - \\
\hline $\mathrm{H} 2 \mathrm{~S}$ & - & - & - & - & - & + \\
\hline URE & - & - & + & - & - & + \\
\hline TDA & - & - & - & - & - & + \\
\hline IND & + & - & - & - & - & + \\
\hline VP & - & - & + & - & - & - \\
\hline GEL & - & - & - & - & - & - \\
\hline GLU & + & - & + & + & + & + \\
\hline MAN & + & - & + & + & - & - \\
\hline INO & - & - & + & - & - & - \\
\hline SOR & + & - & + & + & - & + \\
\hline RHA & + & - & + & + & - & - \\
\hline SAC & - & - & + & - & - & + \\
\hline MEL & + & - & + & - & - & - \\
\hline AMY & - & - & + & - & - & - \\
\hline ARA & + & - & + & - & - & - \\
\hline OX & - & - & - & - & - & - \\
\hline $\mathrm{NO} 2$ & + & - & + & + & + & + \\
\hline $\mathrm{N} 2$ & - & - & - & - & - & - \\
\hline MOB & + & + & - & + & - & + \\
\hline $\mathrm{McC}$ & + & + & + & + & + & + \\
\hline OF-O & + & + & + & + & + & + \\
\hline $\mathrm{OF}-\mathrm{F}$ & + & - & + & + & + & + \\
\hline
\end{tabular}

where they confirmed as

Genus1: E.coli; Genus 2: P.flouresencce; Genus 3; K.pneumonia; Genus 4: Salmonella cloerasuls; Genus 5; Shigella sp.; Genus 6: Proteus vulgaris.

API (Analytical Profile Index) 20E presented is a biochemical panel for identification and differentiation of members of the family Enterobacteriaceae. In API 20E for identification of members of the family Enterobacteriaceae, the plastic strip holds twenty minitest chambers containing dehydrated media having chemically-defined compositions for each test.

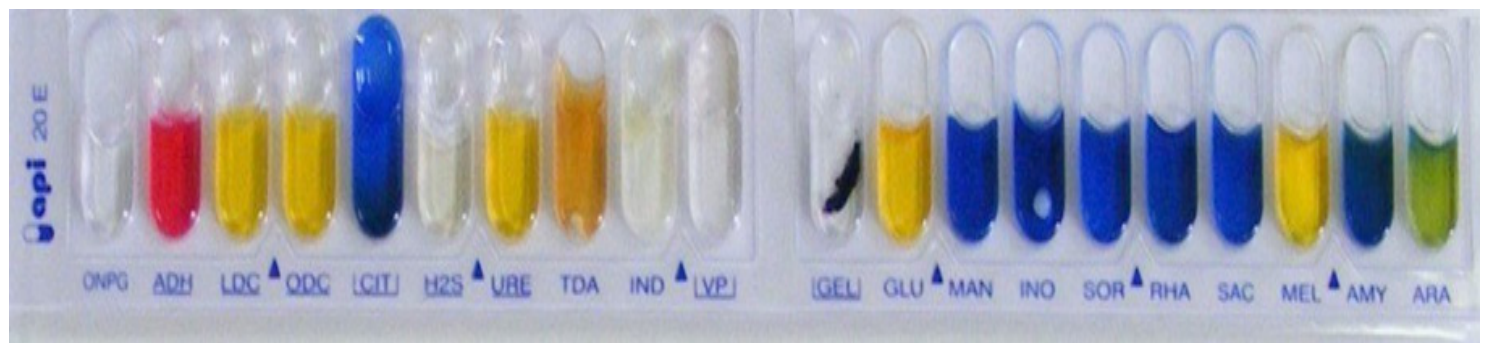

API 20 E Biochemical Test Strip

Egypt. J. Chem. 60, No. 6 (2017) 
1- ONPG: test for $\beta$-galactosidase enzyme by hydrolysis of the substrate o-nitrophenyl-b-Dgalactopyranoside

2-ADH: decarboxylation of the amino acid arginine by arginine dihydrolase

3-LDC: decarboxylations of the amino acid lysine by lysine decarboxylase

4- ODC: decarboxylations of the amino acid ornithine by ornithine decarboxylase

5- CIT: utilization of citrate as only carbon source

6- H2S: production of hydrogen sulfide

7- URE: test for the enzyme urease

8- TDA (Tryptophan deaminase): detection of the enzyme tryptophan deaminase: Reagent to putFerric Chloride.

9- IND: Indole Test-production of indole from tryptophan by the enzyme tryptophanase . ReagentIndole is detected by addition of Kovac's reagent.

10- VP: the Voges-Proskauer test for the detection of acetoin (acetyl methylcarbinol) produced by fermentation of glucose by bacteria utilizing the butylene glycol pathway

11- GEL: test for the production of the enzyme gelatinase which liquefies gelatin

12- GLU: fermentation of glucose (hexose sugar)

13- MAN: fermentation of mannose (hexose sugar)

14- INO: fermentation of inositol (cyclic polyalcohol)

15- SOR: fermentation of sorbitol (alcohol sugar)

16- RHA: fermentation of rhamnose (methyl pentose sugar)

17- SAC: fermentation of sucrose (disaccharide)

18- MEL: fermentation of melibiose (disaccharide)

19- AMY: fermentation of amygdalin (glycoside)

20- ARA: fermentation of arabinose (pentose sugar)
Classification of the surface and groundwater samples according to trilinear plotting system (Piper's 1953 diagram)

The piper trilinear diagram combines three distinct fields for plotting, two triangular fields at the lower left and lower right, respectively, and an intervening diamond-shaped field. The center diamond-shaped field is used to show the overall chemical character of the groundwater by a third single point plotting, which is at the intersection of rays projected from the plotting of cations and anions.

From Fig.10, it is clear that the majority of the groundwater samples $(61 \%)$ are located in area (7) where noncarbonated alkali (primary salinity) exceed 50 percent, that is, chemical properties of the groundwater are dominated by alkalis and strong acids while $(32 \%)$ of the groundwater samples are located in area (9) where no one cation-anion pair exceeds 50 percent. Also, (3\%) of groundwater samples are located at area (5) where carbonate hardness (secondary alkalinity) exceeds 50 percent, that is, chemical properties of the groundwater are dominated by alkaline earth and weak acids. This means that most of the groundwater samples $(60 \%)$ in the study area are affected by El Khashab and Masjid Musa canals water while the rest of the samples $40 \%$ are affected directly by El Saff canal for wastewater by seepage during its movement.

Evaluation of water samples quality for human drinking according to salinity

According to (ASTM) [12], one can be

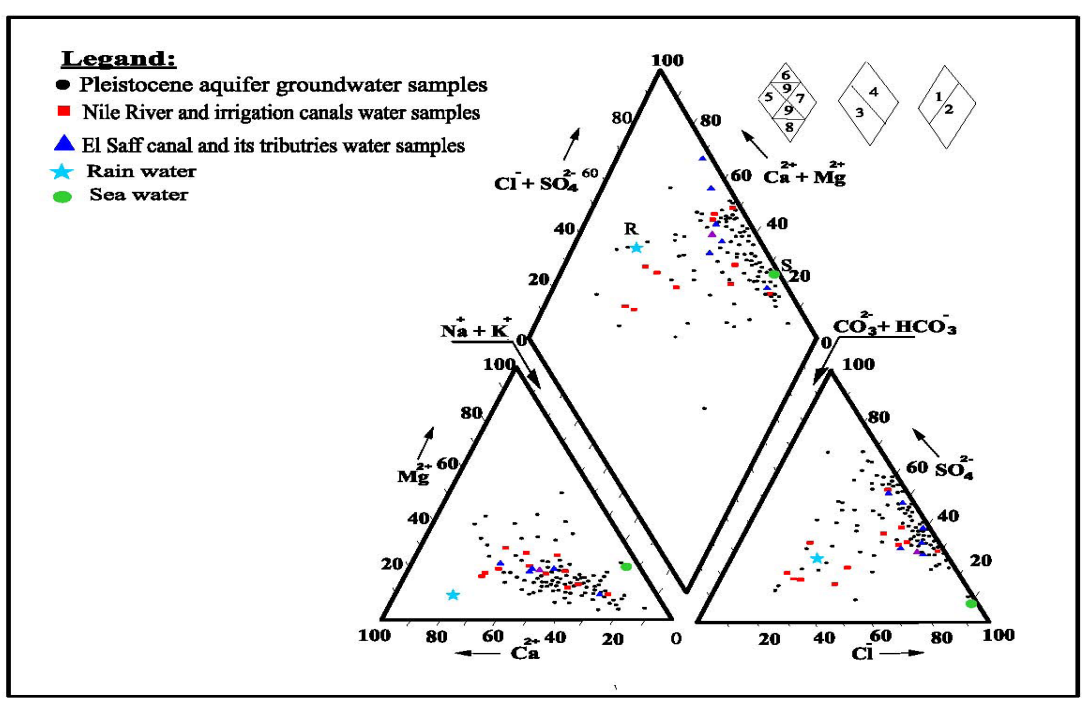

Fig. 10. Trilinear plotting system (Piper's diagram) for the surface and groundwater in the study area. 
conclude that $(56 \%)$ of surface water samples in the study area are suitable for drinking since they have concentrations of water salinity $(1000 \mathrm{mg} / \mathrm{L})$ and major ions less than that of the permissible limits, while (44\%) of surface water samples are unsuitable for drinking as they have concentrations of water salinity more than that of the permissible limit. Most of the groundwater samples $(82 \%)$ of the Pleistocene aquifer in the study area unsuitable for drinking as they have concentrations of water salinity more than that of the permissible limit. On the other hand, the rest of the groundwater samples $(18 \%)$ are suitable for drinking since they have concentrations of water salinity and major ions less than that of the permissible limits.

\section{Evaluation of water samples quality for human} drinking according to trace elements

Majority of the surface water and groundwater samples in the study area $(90 \%)$ were unsuitable for drinking as they have $\mathrm{Fe}, \mathrm{Sr}, \mathrm{B}$ and $\mathrm{NO}_{3}^{-}$ concentrations more than the acceptable limits [15] in different portions.

Evaluation of water samples for irrigation according to U.S. salinity laboratory staff classification (1954)

Most of the irrigation canals water samples $(60 \%)$ are considered good water as they are located at C2-S1 and C3-S1 zones, where they can be used for all soil except the soil with restricted drainage, while about $40 \%$ of the irrigation canals water samples are considered moderate water for irrigation as they located at $\mathrm{C} 3-\mathrm{S} 2$ and $\mathrm{C} 4-\mathrm{S} 2$ zones where represents an appreciable sodium hazard in fine-texture soils having high cation exchange capacity, especially under low leaching condition, unless gypsum is present in the soil.

For groundwater samples in study area, about $23 \%$ of water samples are good for irrigation as they located at C3-S1 and C4-S1 zones, where they can be used for all soil except the soil with restricted drainage, while about $30 \%$ of the groundwater samples are moderate water for irrigation as they located at $\mathrm{C} 3-\mathrm{S} 2$ and $\mathrm{C} 4-\mathrm{S} 2$ zones where represents an appreciable sodium hazard in fine-texture soils having high cation exchange capacity, especially under low leaching condition, unless gypsum is present in the soil. Also, $18 \%$ of the groundwater samples are intermediate water for irrigation as they located at C4 - S3 zone where may produce harmful levels of exchangeable sodium in most soils. Finally, the rest of the groundwater samples $(30 \%)$ are bad water for irrigation as they located at $\mathrm{C} 4-\mathrm{S} 4$ zone where it not suitable for irrigation under ordinary condition.

In conclusion, most of the surface water and groundwater samples in the study area are suitable for irrigation.

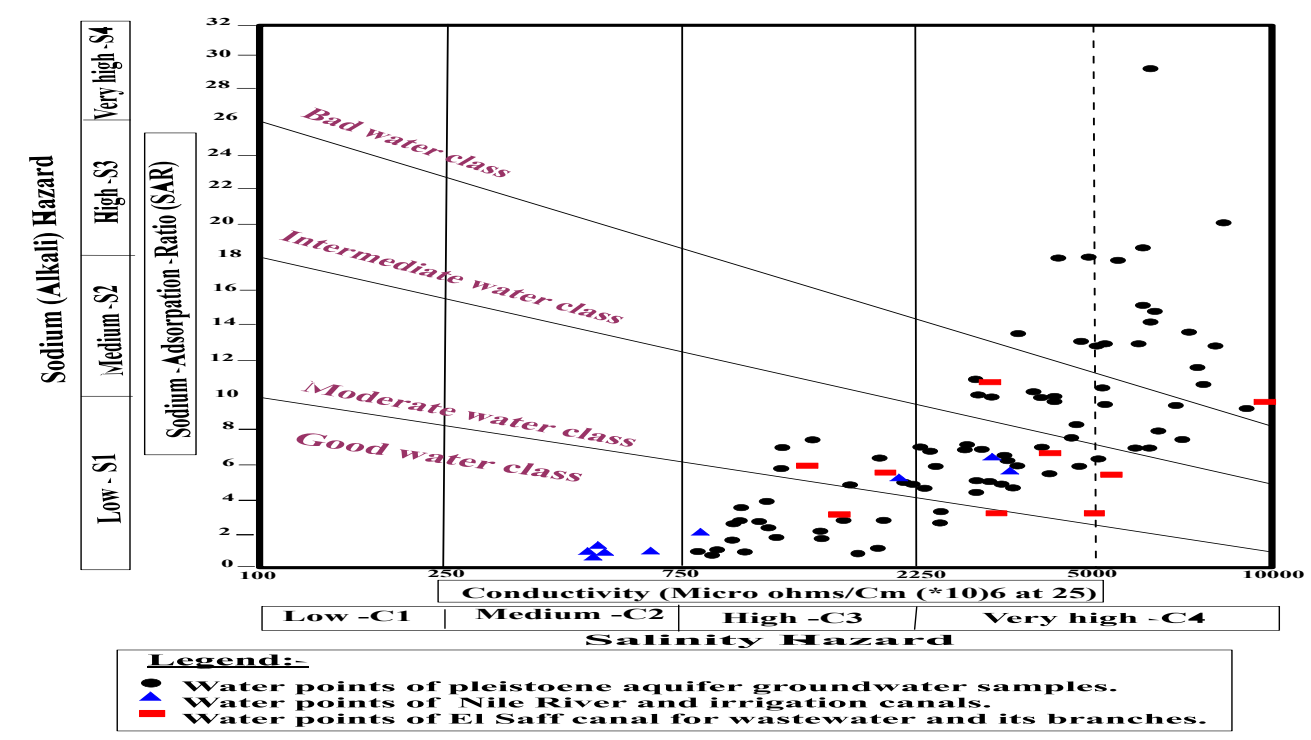

Fig. 11. The U.S. salinity laboratory staff classification (1954).

Egypt. J. Chem. 60, No. 6 (2017) 


\section{$\underline{\text { Summary and Conclusion }}$}

The current research is carried out to throw light on the pollutants detection and their impact on human health as well as evaluate these water resources for different purposes in Atfih area, Giza governorate, Egypt.

To achieve the aim of this research, water pollution was discussed on the basis of determining the inorganic and bacteriological constituents during analyses of fifty (50) water samples collected within March 2016. The collected water samples are corresponding to all available water sources included (8) surface water (Nile River, and El Khashab and Masjid Musa canals as well as El-Saff waste water canal) and (42) groundwater samples.

The results revealed that Nile River water sample has heavy metal concentration less than acceptable limit. For the surface water samples (El Khashab and Masjid Musa canals) and El Saff canal for wastewater samples are variably polluted by $\mathrm{Fe}$ and $\mathrm{Sr}$ as well as $\mathrm{B}$ and $\mathrm{NO}_{3}{ }^{-}$. The high concentrations of Fe and Srin El Khashab and masjid Musa canals are due to these canals are affected by El Saff canal which considered as an acceptor for the industrial wastes that coming from the factories existed in Helwan area which located at north of the study area, also these canals received industrial wastes from factories existed in the study area that discharged their wastes in these canals at these localities. In addition, high $\mathrm{Fe}$ concentrations are detected in irrigation canals that can be attributed to the deposition of most of the waste suspended materials in these canals.

The high concentrations of $\mathrm{Fe}$ and $\mathrm{Sr}$ in the majority of groundwater confirm that there is seepage from El Khashab and Masjid Musa canals and from El Saff wastewater canal that contains relatively high soluble metals as well as downward infiltration of excess amounts of irrigation water rich in fertilizers and pesticides to the groundwater aquifer. The relatively high concentrations of boron in El Khashab, Masjid Musa canals and El Saff wastewater canal are due to the discharge of sewage water and industrial wastewater rich in sodium tetraborate (borax) which is widely used as a cleaning aid. While the high boron concentrations in the groundwater is due to downward infiltration of excess irrigation water and drainage water rich in fertilizers and pesticides.
About ( $83 \%$ ) of the groundwater samples have nitrite concentrations more than the permissible limit of pollution, this is due to the effect of the wastewater of El Saff canal (seepage from El Saff wastewater canal to groundwater at these localities).

Majority of surface water (El Khashab and Masjid Musa canals) samples and groundwater samples in the study area are unsuitable for drinking as they have $\mathrm{Fe}, \mathrm{Sr}, \mathrm{B}$ and $\mathrm{NO}_{3}^{-}$more than that of the permissible limit.

By comparing the current study with the previous studies in the study area indicate that the state of the chemistry of water resources became very bad due to the accumulation of pollutants by time.

In conclusion, most of the surface water and groundwater samples in the study area are suitable for irrigation.

\section{References}

1. Abu-Shady M.R., El-Moatassem M., Heikal M.T. and Khalafalla G.M., Microbiological quantity of the river Nile stretch flows through Cairo. In: Second International Conference on Potable Water Management and Water Treatment Technologies, Cairo, Egypt, p: 96 (1996).

2. El-Gohary F.A., Industrial wastewater management in Egypt. Cairo: Italian-Egyptian Study days on the Environment (1994).

3. El sheikh A.E., Hydrological assessment of the water logging problem in El saff-Atfih area, southeast Cairo, Egypt. Assiutuniv. J. of Geology, 37 (2), 159188 (2008).

4. Abbaspour N., Hurrell R. and Kelishadi R., Review on iron and its importance for human health. J. Res. Med. Sci. Feb; 19 (2), 164:174 (2014).

5. Environmental Protection Agency (EPA). Strontium (CASRN 7440-24-6). Updated October 31(2014).

6. ZekriMongi and Obreza Tom. Boron (B) and Chlorine (Cl) for Citrus Trees (PDF).IFAS Extension. University of Florida. Retrieved 30 June (2017)

7. Karabooze I., Ucar F., Eltem R., Ozdmir G. and Ates M., Determination of existence and count of pathogenic microorganisms in Izmir Boy. JES 26, pp1-18 (2003).

8. Shawky Z. Sabae and Saleh A. Rabeh, Evaluation of microbial quality of the River Nile water at Demitta 
branch, Egypt. Egyptian Journal of Aquatic Research ISSN: 1687-4285, 33 (1), 301-311(2007).

9. Fleisher J.M., Kay D., Wyer D. and Godfree A.F., Estimates of the severity of illness associated with bathing in marine recreational waters contaminated with domestic sewage. International Journal of Epidemiology, 27, 722-726 (1998).

10. Baron S., Medical Microbiology, $4^{\text {th }}$ ed. The University of texas Midical Branch at Galveston (1996).

11. World Health Organization (WHO), Guideline of Drinking Water quality, $2^{\text {nd }}$ ed Vol.1, World Health organization, Geneva (1993).

12. American society for Testing and Materials (ASTM), In: Water and environmental technology. Annual book of ASTM standards, Sec. 11, Vols. 11.01 and 11.02, Waste Conshohosken, U.S.A (2002).

13. Fishman M.J., and Friedman L.C, Methods for determination of inorganic substance in water and fluvial sediments. U.S. Geo. surv., book 5, Chaĉpter A1. Open File Report, pp.85-495, Denver, Colorado, U.S.A (1985).

14. American Public Health Association (APHA), Standard method for the analysis of water and wastewater,Washington, DC, USA $19^{\text {th }}$ ed (1995).

15. Hausler W.J. and Koontz F.P., Brucellusis. In: Diagnostic Procedures For Bacterial, Mycotic and Parasitic Infections, $5^{\text {th }}$ ed., APHA, New York (1970).

16. World Health Organization (WHO), Guiedline of Drinking water quality, Incorporating First

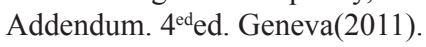

17. Schilling K.E. and wolter C.F., Contribution of base flow to nonpoint source pollution loads in an agricultural watershed. Groundwater. 39, pp. 49-58 (2001).

18. Liu A.G., Ming J.H. and Ankumah R.O., Nitrate concentration in private wells in rural Alabama, United States. Science of the Total Environment, 349, 112-120. (2005).

19. Shaaban-Dessouki S.A., soliman A.I. and Deyab M.A., Environmental characteristics and nutrients distribution in Demietta estuary of the River Nile. Journal of Environmental Science, 6, 159-177 (1993).

20. Geldreich E.E., Buffalo lake recreational water quality: a study on bacteriological data interpretation. Water research, 6, 913-921(1974).
21. Podschun P., pietsch S., Holler C. and Ulmann U., Incidence of Klebsiella species in surface waters and their expression of virulence factors. Appled and Environmental Microbiology, 67 (7), pp. 3325 3327 (2001).

22. McIntoshD. and Austin B., Recovery of an extremely proteolytic from serratialiquefaciensaspathogen of Atlantic salmon, Salmon salar, in Scotland. Journal, of Fish Biology, 36, pp. 765-772 (1990).

23. Piper A.M., A graphic representation in the geochemical interpretation of groundwater analysis. American Geophysical Union Transactions, U.S.A., 25, pp.914-923 (1953).

24. Richard L.A., Diagnosis and Improvement of Saline and alkaline Soils.U.S. Department of Agricultural Handbook, 60, U. S. Gov. Print, office, Washington, DC., U. S. A. p 160 (1954).

(Received 25/9/2017; accepted $9 / 11 / 2017$ ) 


\section{التأثيرات الكيميائية والبكتريولوجية لمياه الصرف على موارد المياه في منطقة أطقيح،} محافظة الجيزة، مصر الكيبانة والبكتر

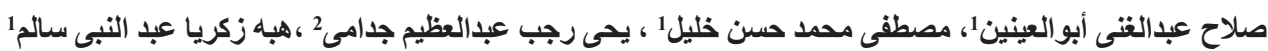

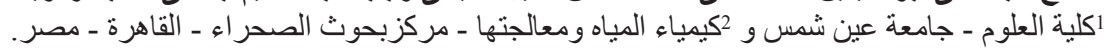

يهدف هذه العمل الى معرفة الخو اص الكيميائيه للمياه السطحيه و المياه الجوفيه في منطقة اطفيح ونتركز الدر اسها

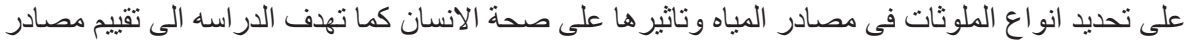

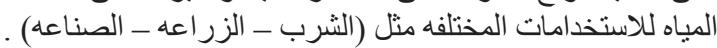

تقع منطقة اطفيح فى الجزء الجنوبى لمحافطة الجيزه على بعد 40 كم تقريبا جنوب شرق القاهره على على الضفه

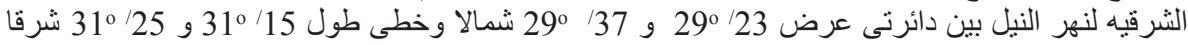

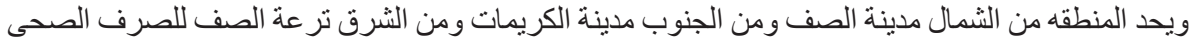

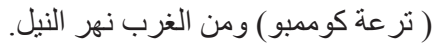

تم جمع 50 عينة مياه منها 8 عينات مياه سطحيه و 42 عينه مياه جوفيه خلال شهر مارس 2016 و عمل الئل

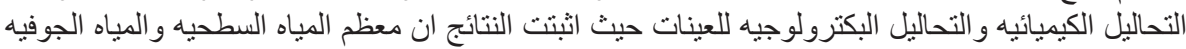

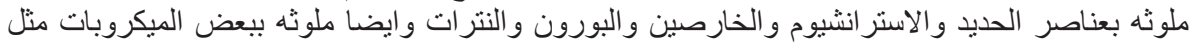

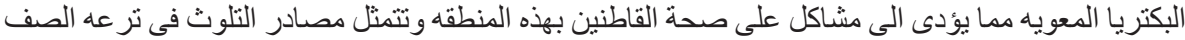
للصرف الصحى وصرف بعض المصانع التى توجد فى مدينتى التبين وحلو ان شمال منطقة الدر اسـاه.

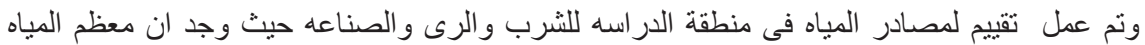

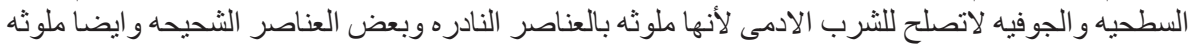

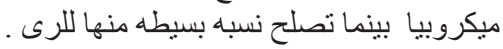

